\title{
MODELAGEM GEOFÍSICA DOS CORPOS MÁFICOS-ULTRAMÁFICOS DE CANA BRAVA, NIQUELÂNDIA E BARRO ALTO, CENTRO DE GOIÁS
}

\author{
Miguel Guterres Carminatti \\ Orientador: Dra. Marta Silvia Maria Mantovani (IAG-USP) \\ 294 p. - Tese (Doutorado) - Defesa 29.09.2006
}

\begin{abstract}
RESUMO. Os Complexos máficos-ultramáticos Cana Brava (CCB), Niquelândia (CNQ) e Barro Alto (CBA) com suas sequêencias vulcano-sedimentares de Palmeirópolis (SVSP), Indaianópolis (SVSI) e Juscelândia (SVSJ) a eles associadas, localizam-se na região centro-norte de Goiás, divisa com Tocantins, dentro da Província Tocantins, entre os Crátons Amazônico e o São Francisco. A anomalia Bouguer positiva segue a forma alongada dos complexos e não apresenta anomalias internas que permitam separar as principais unidades litológicas. Para determinar a forma dos complexos em profundidade foi feito a modelagem gravimétrica em $2 \frac{1}{2} \mathrm{D}$ e $3 \mathrm{D}$ usando perfis residuais e mapa Bouguer residual. A melhor separação regional-residual para os mapas foi conseguida através da aplicação do Método da Omissão, usada no modelo 3D. Para a modelagem $2 \frac{1}{2} \mathrm{D}$ foram utilizados perfis ajustados visualmente para o Complexo Cana Brava e perfis retirados dos residuais obtidos pelo Método da Omissão. Os resultados das modelagens gravimétricas obtidas pelos dois métodos indicam que a maior espessura dos conjuntos se aproxima do centro da área aflorante e que o contato entre as unidades das sequiências vulcano-sedimentares e das rochas máficas-ultramáficas acamadas dos complexos são mergulhantes para oeste. Os modelos $2 \frac{1}{2} \mathrm{D}$ e 0 3D sugerem que os complexos Cana Brava e Barro Alto possuem uma forte forma cuneiforme, para o Complexo Niquelândia a forma encontrada se assemelha a cônica, todos com a maior largura muito próxima da superfície. Há possivelmente presenças de lascas próximas aos limites leste dos complexos Cana Brava e Barro Alto, paralelas a orientação das rochas acamadadas, como sugerido pela presença de valores residuais positivos naquelas regiões. Baseado na geometria encontrada para os complexos pode-se inferir uma mecânica de movimento para os três complexos que explica a forma similar a estruturas tipo pop up de retro empurrão antético e as orientações espaciais das unidades internas. Os resultados obtidos pelo estudo de anisotropia de suscetibilidade magnética reforçam a interpretação dos modelos gravimétricos e apontam para a possibilidade deles terem estado unidos ou muito próximos. A interpretação destes dados sugere um possível modelo de separação e afastamento dos complexos similar à formação de boudins em camadas rúpteis entre camadas dúcteis, sob regime compressivo.
\end{abstract}

ABSTRACT. This thesis is about the gravity and magnetic anisotropy survey on Cana Brava (CCB), Niquelândia (CNQ) and Barro Alto mafic-ultramafic complexes, and associated volcano-sedimentary successions of Palmeirópolis (SVSP), Indaianópolis (SVSI) and Juscelândia (SVSJ). These complexes are situated at the northwestern region of Goiás State, in the Tocantins geotectonic province, between the Amazon and São Francisco Cratons. After regional-residual separation of Bouguer anomalies, obtained through the station omission method, the complexes are delineated by positive residual anomalies, which follow the stretched out shape of the mafic-ultramafic bodies and their volcano-sedimentary sequences. However, internal anomalies that would allow the separation of these units are not observed. Positive anomalies close to the eastern border of Cana Brava and Barro Alto complexes suggest the presence of non-outcropping anomalous bodies, parallel to strike of the layered rocks. The result from the $2 \frac{1}{2} \mathrm{D}$ and $3 \mathrm{D}$ gravity modeling indicate that the greatest thickness of the anomalous bodies falls close to the center of its outcropping area, and the contact between the volcano-sedimentary successions and the mafic-ultramafic layered complexes dips to the west. The Cana Brava and Barro Alto complexes have a wedge shape, while the Niquelândia complex has a conical shape. Based on the geometry found for the complexes, it is suggested that their final shape and their internal structure are conditioned by the thrust-faults that limit those bodies to the east. Results obtained from anisotropy of magnetic susceptibility corroborate the gravity model's interpretation. 